\title{
Childhood disintegrative disorder
}

INSERM

\section{Source}

INSERM. (1999). Orphanet: an online rare disease and orphan drug data base. Childhood disintegrative disorder. ORPHA:168782

Childhood disinterg rative disorder is a rare pervasive developmental disorder with a disease onset before the age of three and characterized by a dramatic loss of behavioral and developmental functioning after atleast two years of normal development. Manifestations of the disease include loss of speech, incontinence, communication and social interaction problems, stereotypical autistic behaviors and dementia. 